\title{
THE NEW HEGEMON? CONTINGENCY AND AGENCY IN THE ASIAN AGE
}

\author{
Jennifer Bair \\ Department of Sociology \\ University of Colorado \\ Jennifer.Bair@Colorado.edu
}

Adam Smith in Beijing is an ambitious sequel to the work that is widely regarded as Giovanni Arrighi's most important, The Long Twentieth Century. Much like this earlier book, Adam Smith in Beijing is a long, sweeping and provocative exploration of capitalism's past, present, and future. In The Long Twentieth Century, Arrighi analyzed the 700 year history of the modern world system as a series of cycles of accumulation, each of which occurred under the auspices of a hegemonic power, and each of which included a period of material expansion followed, late in the cycle, by a shift in the locus of capital accumulation to the financial sector. Arrighi's analysis of four successive regimes - the Genoese, Dutch, British, and U.S.- drew on Braudel's concept of the "autumn of a hegemonic system," which refers to the period of financial expansion marking the maturation of a particular regime of accumulation and its eventual displacement by a new one. This perspective enabled Arrighi to understand the financialization of the world economy, proceeding apace at the time under then-President Clinton, in the context of the longue durée in which one (declining) hegemon's autumn is another (rising) hegemon's spring.

If The Long Twentieth Century analyzed the systemic cycle of accumulation as a recurrent and foundational structure of capitalism's historical development, Adam Smith in Beijing explores a particular moment in this process. In Arrighi's view, we are experiencing a transition from one regime to a new, as-yet undetermined one, and the (modest) question he sets out to answer is what this transition augurs for the future of global capitalism, the health of the planet, and the well-being of humanity.

It is in this sense that the more recent book begins where the earlier one leaves off: It is now late autumn for the U.S.-centered regime of accumulation, and the era of American hegemony is over. The war in Iraq, and the failure of the larger Project for a New American Century of which it was part, is central for understanding how the relationship of the US to the rest of the world reached the point of "domination without hegemony" that characterizes it today. Arrighi's contention is that whatever the final outcome of the war itself, the difficulties that the US encountered in waging it were deeply revealing, both of its inability to enlist the widespread support of other countries, who no longer trust the United States to lead the world in ways that enhance the well-being and security of all, and of its dependence on military might to sustain its economic and political objectives. Insofar as this neoconservative-inspired project was intended to stave off decline and prolong America's power, its implementation under the Bush administration proved profoundly counterproductive, as it laid bare in the starkest way imaginable the limits of that power.

In The Long Twentieth Century, Arrighi hypothesized that the dislocations of the 1970sthe Vietnam war, the social and political unrest that surrounded it, the economic shock of the oil crisis and the long period of malaise that followed-could be interpreted as the signal crisis of American hegemony. Although he made no specific predictions about the nature or precise timing

Copyright $@$ 2009, American Sociological Association, Volume XV, Number 2, Pages 220-227 ISSN 1076-156X 


\section{JOURNAL OF WORLD-SYSTEMS RESEARCH}

of the eventual terminal crisis that would some decades hence mark the definitive end of U.S. hegemony, one of the central claims of Adam Smith in Beijing is that the Iraq war constitutes such a crisis. Subsequent events - specifically, the global economic meltdown precipitated by the subprime mortgage morass in U.S. financial markets-confirmed Arrighi's views in this regard, as he stated unequivocally in a recent interview with David Harvey, published earlier this year in New Left Review: "With the bursting of the housing bubble, what we are observing now is, quite clearly, the terminal crisis of US financial centrality and hegemony" (2009, p. 90).

The decline of the American-centered regime of accumulation is only one half of the central argument in Adam Smith in Beijing, and although Barack Obama's election in 2008 raises a number of new and interesting questions about whether or not the U.S. will more intelligently, or at least less catastrophically, manage a decline that is, in Arrighi's view, unavoidable, his overall argument about the autumn of the U.S.-led regime is neither as novel nor as provocative as his analysis of the global political-economic configuration to which we are transitioning. In this regard, Arrighi revises his earlier analysis somewhat: While both The Long Twentieth Century and Adam Smith in Beijing claim that the center of the world economy is shifting to East Asia, the former focused on Japan as the region's largest economy and the one leading its rise on the world stage; by the time Arrighi finished what we now know will be his last book, China's decade-plus of unprecedented growth cemented its status as the most significant player in the East Asian capitalist archipelago.

While Arrighi is hardly alone in noting the implications of China's ascent for the future of the global economy, he offers a distinctive interpretation of its trajectory which draws on the theory of economic development elaborated by Smith in The Wealth of Nations. Like his analysis of the U.S. regime's "autumn," China's economic emergence (or as Arrighi sees it, reemergence), is approached from the perspective of the longue durée; while many have interpreted China's adoption of market reforms as a sharp break from its socialist past, Arrighi sees connections between the dramatic growth that China is experiencing today and a distinctive, regionallyspecific trajectory that extends several centuries back into East Asian history. His discussion of this model draws heavily from work by scholars of East Asia, especially the work of Kaoru Sugihara, who developed the concept of the "industrious revolution," both to describe this growth model, which is based on labor-intensive forms of production and husbanding of natural resources, and to differentiate it from the ecologically more destructive (and ultimately unsustainable) capital-intensive development path of the West, whereby energy and machinery are progressively substituted for labor.

Arrighi's argument is that China's contemporary resurgence is a vindication of Adam Smith's economics, which, far from advocating the free-market fundamentalism of the "there is no alternative" variety, actually acknowledged multiple ways to grow the wealth of a nation. Indeed, Smith encouraged the policymakers of his day to learn from the experience of those countries, China being the exemplar, that were following a "natural" path to development based primarily on agricultural and eventually industrial production for the domestic market, with foreign commerce playing a belated and secondary role. In contrast, for Smith, the European countries had followed an "unnatural” path in which commercial capital and long-distance trade figured prominently. The outward orientation of this model meant that economic growth was fundamentally tied to the exploitation of foreign resources and foreign markets of the sort that Britain's empire encompassed. Arrighi emphasizes that Smith, appreciating the benefits that the natural path to development provides relative to the one forged by the European nations, advised 
the policymakers of his day to steer England towards the former.

It is likely that Smith's entreaties fell on deaf ears in this regard, however, since the exploitation of foreign resources and markets on which the "unnatural" model depended was already well advanced. Smith himself was aware that countries following different paths to national wealth would find it increasingly difficult to avoid the intersection of other routes, given the linkages which European colonialism was forging between distant parts of the world. While Smith acknowledged the "dreadful misfortunes" that European imperialism brought to the native populations of the conquered nations, he also gestured, in a passage Arrighi quotes in his introduction, towards the possibility of a convergence in the wealth of nations east and west that would permit "the inhabitants of all the different quarters of the world...to arrive at that equality of courage and force which, by inspiring mutual fear, can alone overawe the injustice of independent nations into some sort of respect for the rights of one another" (p. 3).

This conjecture serves as Arrighi's point of departure for Adam Smith in Beijing. The century following the publication of The Wealth of Nations was characterized, not by a narrowing of the gap between east and west, but instead by what Ken Pomeranz termed the "Great Divergence." This gulf between the two regions endured well into the next century, surviving the transition from a U.K.-led regime of accumulation to one centered on the United States. Yet the central thesis of Arrighi's book is that "the failure of the Project for a New American Century, and the success of Chinese economic development, taken jointly, have made the realization of Smith's vision of a world-market society based on equality among the world's civilizations more likely than it ever was in the almost two and a half centuries since the publication of The Wealth of Nations” (p. 8).

The argument is elaborated in four sections, though this review focuses primarily on the first and last of these. In the three chapters comprising part 1 of the book, Arrighi offers his rereading of Smith. I suspect that, unlike the many enthusiasts of unfettered markets whose interest in Smith does not extend much beyond a ritualistic invocation of "the invisible hand" metaphor, many of Arrighi's readers will have actually spent some time with The Wealth of Nations. To the extent that they have, the author's attempts to defend Smith from the more vulgar of his interpreters are probably unnecessary. But Arrighi's principal objective in this first section is to convince us that Smith's political economy can help us understand what Arrighi contends are non-capitalist market economies (as opposed to the capitalist market economies that Marx analyzed) "such as China was prior to its subordinate incorporation in the globalizing European system of states, and might well become again under totally different domestic and worldhistorical conditions" (p. 8).

The fourth and final section of the book is likely to be the most controversial, since it presents a view of the market society emerging in China that some will consider, not without reason, to be quite benign. It begins with a discussion of the U.S. response to China's ascent, or more accurately, the lack of a coherent response, which reflects, among other things, U.S. dependence on Chinese purchases of Treasury bonds. Arrighi explains that one of the challenges that the United States confronts in dealing with China is the fact that "the entire East Asian system of interstate relations has been characterized by a long-term dynamic that contrasts sharply with the Western dynamic" to which U.S. foreign policy is oriented (p. 333). Here Arrighi lays out a history of the region's "natural path" to development, which extends back to the formation of overseas trading networks between China and maritime Asia in the late $13^{\text {th }}$ century, culminating in a period of robust economic growth in the eighteenth century. 


\section{JOURNAL OF WORLD-SYSTEMS RESEARCH}

East Asia's economic eclipse began in earnest with China's defeat in the Opium Wars during the middle decades of the nineteenth century, and it lasted for nearly a hundred years. Although the region's eventual reemergence was enabled by U.S. sponsored efforts to reconstruct Japan after the Second World War, American influence in Asia waned in the aftermath of its defeat in Vietnam, when United States hegemony was, according to Arrighi's periodization, experiencing its signal crisis of the 1970s. Over the course of the next decade, Japan emerged as a growing power not just in the region, but in the global economy; its government (through the purchase of Treasury securities) became a major investor in the United States, while its corporations became major suppliers of merchandise to U.S. consumers and major competitors to U.S. manufacturers. A particular organizational model, quite distinct from the verticallyintegrated Fordist one that structured American industry, was regarded as the key to Japan's export dynamism. What Arrighi emphasizes here, however, is that the "Japanese" model rested on a Chinese foundation: In the 1970s, when the Japanese subcontracting system began to extend across national borders, this "spillover [into neighboring countries] relied heavily on the business networks of the overseas Chinese, who were from the start the main intermediaries between Japanese and local business, not just in Singapore, Hong Kong, and Taiwan, but in most southeast Asian countries, where the ethnic Chinese minority occupied a commanding position in local business networks” (p. 347).

Japan's dynamic rise was eventually curtailed, due both to the U.S.'s success in bringing diplomatic and geopolitical pressure to bear, resulting in measures (discussed in chapter four) such as voluntary export restrictions on Japanese products and the revaluation of the yen under the Plaza Accord, and to the efforts of U.S. industry to restructure its own production networks along the lines of Japan's more flexible organizational model. Asian factories thus became the battleground on which struggles between Japanese and American companies played out, but despite the convergence of the U.S. towards the Japanese model, Arrighi emphasizes that "the main beneficiary of the mobilization of East Asian subcontracting networks in the intensifying competitive struggle among the world's leading capitalist organizations was neither Japanese nor US capital. Rather, it was another legacy of the East Asian development path: the overseas Chinese capitalist diaspora” (p. 348). Arrighi thus provides a fresh perspective on the sourcing practices of a company like Wal-Mart, which, in 2008, planned to procure \$9 billion worth of merchandise from China. While some analysts see these buyer-driven commodity chains as an emergent organizational form in the post-War international economy, enabled by U.S. commercial capital and the rise of giant retailers that manage far-flung subcontracting networks, Arrighi emphasizes the pivotal role played by the overseas Chinese business community, which serves to link foreign buyers to global suppliers that manufacture many of the goods sold in their stores or under their label. Rather than being pioneered by Wal-Mart, Arrighi, citing the work of Gary Hamilton and others, notes that subcontracting arrangements of this sort were already "a distinctive feature of big business in late imperial China, and remained the dominant form of business organization in Taiwan and Hong Kong up to the present” (p. 348).

With China having displaced Japan as the center of gravity in a resurgent East Asia, the final chapter of Adam Smith in Beijing offers an analysis of the "origins and dynamics" of its ascent. Like other observers of China's meteoric rise, Arrighi is impressed not just by China's dominance of foreign markets, but also by its apparent success in moving up the value chain. However, Arrighi sees China's export boom as a manifestation rather than a cause of the economy's success, which, he emphasizes, is based less on foreign direct investment than on an 
indigenous development tradition. Just as Arrighi strives to recuperate Adam Smith from his adoption by market radicals, so too does he aim to recover the Chinese miracle from its appropriation by those who use it to buttress neoliberal policy prescriptions for the developmental cure. Here Arrighi returns to the discussion of Smith's "natural" path to national wealth, and argues that key features of the Chinese experience-particularly its gradualism and the role that the state has played in managing the introduction of market reforms and promoting particular objectives, chiefly social stability-approximate very poorly the stylized model of the Washington Consensus; they are further, he contends, deeply rooted in Chinese history and China's central role in an East Asian development trajectory that was interrupted in the nineteenth century by the region's subordinate incorporation into the European-centered regime of accumulation.

If Arrighi's interpretation of China's future, and the emergence of what he suggests may be an "Asian age," are the most contentious aspects of his argument, it is important to acknowledge that his optimism about a China-centered, East Asia-based world-market society is based less on a romanticization of the country's present than on a particular reading of its past, and a particular understanding of how that past matters. The Communist Revolution was a critical episode in China's history, but the trajectory shaping contemporary developments in Asia reaches far back beyond Mao. For example, Arrighi claims that modernization was pursued during the Maoist period not through the destruction of the peasantry, as in the USSR, but "through the economic and educational uplifting of the peasantry" (p. 374). Yet the agricultural dimension of China's ascent is not regarded solely as a legacy of the Revolution; Instead, Arrighi sees a connection between the contemporary status of China's rural labor force and an East Asian development model described by Smith two hundred years prior to the Cultural Revolution-that is, a "tradition of market economy, which, more than any other, mobilized human rather than non-human resources and protected rather than destroyed the economic independence and welfare of agricultural producers" (p. 365).

It is possible to see here how the lineage Arrighi draws from the "natural" path to development described in The Wealth of Nations to the contemporary Chinese ascent descends from his own intellectual trajectory and specifically, his early work on the political economy of Rhodesia. Arrighi's first forays into comparative-historical sociology elaborated on the way in which the dispossession of the peasantry in southern Africa hindered the development of capitalism there by eliminating the ability of the rural labor force to subsidize its own reproduction, and capital accumulation. Among the implications that Arrighi drew from his research in Africa, the most significant was his rejection of proletarianization as a necessary condition of capitalist development. This sensitivity to the historically contingent and variable ways in which the peasantry can be incorporated into and shape development trajectories is reflected here in Arrighi's discussion of China's Township and Village Enterprises (TVEs) as an example of "accumulation without dispossession."

Some of the other connections that Arrighi attempts to draw between Smith's "natural" path and the Chinese ascent are more difficult to see, at least for this reader. For example, it is hard to square Arrighi's argument about the comparative advantage provided by the selfmanagement skills of Chinese labor with the many ethnographic accounts of conditions on China's shop floors. His interpretation of the salutary effects of the East Asian development path for labor draws from Sugihara's work on the industrious revolution, as he recently explained in the New Left Review interview with David Harvey: "In the industrious revolution there is a 


\section{JOURNAL OF WORLD-SYSTEMS RESEARCH}

mobilization of all the household's resources, which develops, or at least preserves, managerial skills among the laborers” (2009, p. 86). Arrighi claims that this aspect of the East Asian experience is "pretty crucial to understanding the present Chinese rise; that having preserved these self-management skills through serious limitations on the process of proletarianization in a substantive sense, China can now have an organization of the labor process that is more reliant on the self-management skills of labor than elsewhere. This is probably one of the main sources of the competitive advantage of China under the new circumstances” (p. 86).

In Adam Smith in Beijing, Arrighi also acknowledges the "countless episodes of superexploitation, especially of migrant workers" in China (p. 360), but the balance of the argument is weighted towards explaining that the high quality of Chinese labor is, first, a legacy of East Asia's "natural" development path, and second, a competitive advantage that helps explain why China has fared so much better than all the other countries offering large reserves of low-priced labor to mobile capital. Yet, it is a challenge to reconcile this profile of a self-directed labor force with the portrait that emerges from ethnographic research on workers in China, many of them young, female migrants from rural areas employed in the south's export-processing zones. While these findings are not necessarily generalizable to Chinese industry as a whole, since they reflect the experience of workers employed in the relatively labor-intensive segment (textiles, electronics) of what is an increasingly diverse manufacturing sector, several studies nevertheless describe labor regimes that tend towards extreme paternalism at best, with workers having little autonomy, not just over the production process, but "off the job" as well, given the prevalence of dormitory living arrangements for migrant workers (Lee 1998, Ngai 2005; Wright 2005).

The reader may also take issue with some of Arrighi's predictions about the dynamics of the China-centered, world-market society that he believes is emerging. It is not entirely clear why, for example, Arrighi is cautiously optimistic that China's ascent is the harbinger "of that greater equality and mutual respect among peoples of European and non-European descent that Smith foresaw and advocated 230 years ago" (p. 379) as opposed to a harbinger of a new Asiancentered regime of accumulation in which China replaces the United States as the hegemonic power. This is a question that Arrighi was asked in his NLR interview with David Harvey, but his answer, which refers to the specificities of China's geopolitical position and the historical importance of commercial, as opposed to political or military ties, between China and its neighbors, is not entirely satisfying. It seems to rely on Arrighi's belief that the nexus between capitalism, militarism, and imperialism on which past regimes of accumulation have rested is somehow incompatible with an eastern hegemon; Arrighi's argument that an emergent Asiancentered world-market society will differ in fundamental ways from the regimes of accumulation that descended from the European path to development would appear to rest primarily on an assumption that the contours of China's future course, as opposed to simply its present, will be profoundly shaped by its past.

Yet the epilogue to Adam Smith in Beijing emphasizes the contingent nature of the transition we are witnessing. Although Arrighi is certain that it is the autumn of U.S. hegemony, and he seems equally confident that the Asian era that is emerging will be presided over by a fundamentally different kind of hegemonic power, he is not at all sure what that power will look like or how it will be exercised. It may lead to a new and more powerful Bandung, since unlike the earlier non-aligned movement, which rested on ideological and political foundations, a new alliance of the South would be buttressed by the economic might not just of China, but also of India. Indeed, many observers have noted China's closer alignment with the countries of the 
global South, perhaps most notably after its participation in the so-called G-20 plus bloc of developing countries, whose call for liberalization of Northern agricultural markets as a prerequisite for progress on the North's agenda contributed significantly to the failure of the WTO ministerial in Cancun in 2005. Yet while China may be deploying power of both the soft and hard varieties, it is not entirely clear how its efforts will be received. The Sinophobia characterizing some discussions of China's ascent in U.S. media are not surprising, especially since they echo earlier anxieties about Japan's rising economic power, but the declining hegemon is not the only country concerned about the implications of East Asia's rise; China is likely to be perceived as much a competitor as an ally by countries whose own development strategies rest on export-led growth, and thus success in global markets that are currently being dominated by Chinese imports.

There are also massive contingencies internal to China which will shape the kind of regime that is emerging. Among these Arrighi acknowledges the three most important, even if they do not receive the more extended treatment they merit. First is the extent to which the husbandry of nature that Arrighi considers characteristic of the "natural" development path is able to shift China off the route, forged by the European powers whose revolution was industrial rather than industrious, of ecologically-destructive growth, and onto a trajectory that is less harmful to the environment. The second factor affecting China's, and the world's, future is the extent to which the heightened inequality and increased economic insecurity that characterized the reform process through the 1990s will be countered by a renewed commitment on the part of the Chinese state to the social protections and welfare commitments of the sort that are supposed to be signaled by Hu Jintao's pledge of a "new socialist countryside.” Since Arrighi does not entertain romantic notions about the enlightened benevolence of the CCP, or any other form of state power, this second factor is, in turn, contingent on a third: the extent to which the Chinese working class will push the state in the direction of a more egalitarian, sustainable, and humane mode of economic development. Arrighi's expectations in this regard are rather high, since, as he notes "Chinese peasants and workers have a millennial tradition of unrest that has no parallel anywhere else in the world” (2009, p.79).

Arrighi says little about the possibility of democratization, or political participation more generally in China, but he closes Adam Smith in Beijing by noting that the significant wave of protest that has erupted throughout China in recent years has already "prompted a major reorientation of Chinese policies towards a more balanced development between rural and urban areas, between regions, and between economy and society” (p. 389); Elsewhere, however, he acknowledges that the balance of forces between the classes in China is still up for grabs at the moment” (2009, p. 80). Arrighi's tone throughout this interview for the New Left Review is more cautious than the one characterizing Adam Smith in Beijing. He repeatedly emphasizes that "[i]t's unclear where China is headed today. I'm not putting bets on any particular outcome..., but we must have an open mind in terms of seeing where it's going” (p. 84). Two themes dominate this conversation with Harvey, and both are characteristic of Arrighi's body of work, not just this fascinating, challenging, and final book of his career. The first is an appreciation for the role of contingency and agency in the unraveling of capitalism as a historical process. The second, related theme is the flexible nature of capitalism across time and space. Any effort to define or analyze capitalism that does not appreciate its tendency to change and adapt to the different social and historical configurations in which it emerges and develops will be unsatisfactory. Among the many rich insights that Arrighi's scholarship offers us, these are perhaps the most valuable for 


\section{JOURNAL OF WORLD-SYSTEMS RESEARCH}

those who carry forward his analytical and political commitments-namely, to better understand the origins of our time in the pursuit of a more just and humane future.

\section{REFERENCES}

Arrighi, Giovanni. 2009. “The Winding Paths of Capital: Interview by David Harvey.” New Left Review 56:61-96.

Lee, Ching Kwan. 1998. Gender and the South China Miracle. Berkeley: University of California Press.

Ngai, Pun. 2005. Made in China: Women Factory Workers in a Global Workplace. Durham: Duke University Press.

Wright, Melissa. 2006. Disposable Women and Other Myths of Global Capitalism. New York: Routledge. 